\title{
Ontario Wood - Worth the Effort
}

he forest industry is a major economic driver for Renfrew County, northwest of Ottawa and running along the Ottawa River, and many residents rely on the employment it provides. The last five years have been particularly difficult for the industry and the downturn continues. However, there seems to be a general lack of awareness of the ability to buy local wood products, particularly by the under 40 demographic exercising their buying power and attempting to be informed consumers. The ability to walk into a big box store and walk out with everything one needs, not knowing where the wood products came from or how they were harvested has led to a net import of wood products in a province capable of growing and producing enough wood to sustain itself. Part of the problem is the lack of accessibility of these products, particularly for consumers who expect to find what they need through internet searching and clear presentation and marketing.

Studies have shown that there is an appetite across all demographics for purchasing Ontario-produced wood for home projects if it is available and meets criteria of price, quality and durability. The Province's Ontario Wood promotion initiative is a step in the right direction but the problem remains that many products available from local mills and craftsmen may not be available in local retail stores. Third party certification is highly publicized and available in stores but in no way provides assurance that wood comes from Ontario or even Canada. The County of Renfrew has initiated a project to compile and make available a resource for locally grown and produced wood products, aiming to benefit the local economy and pro-

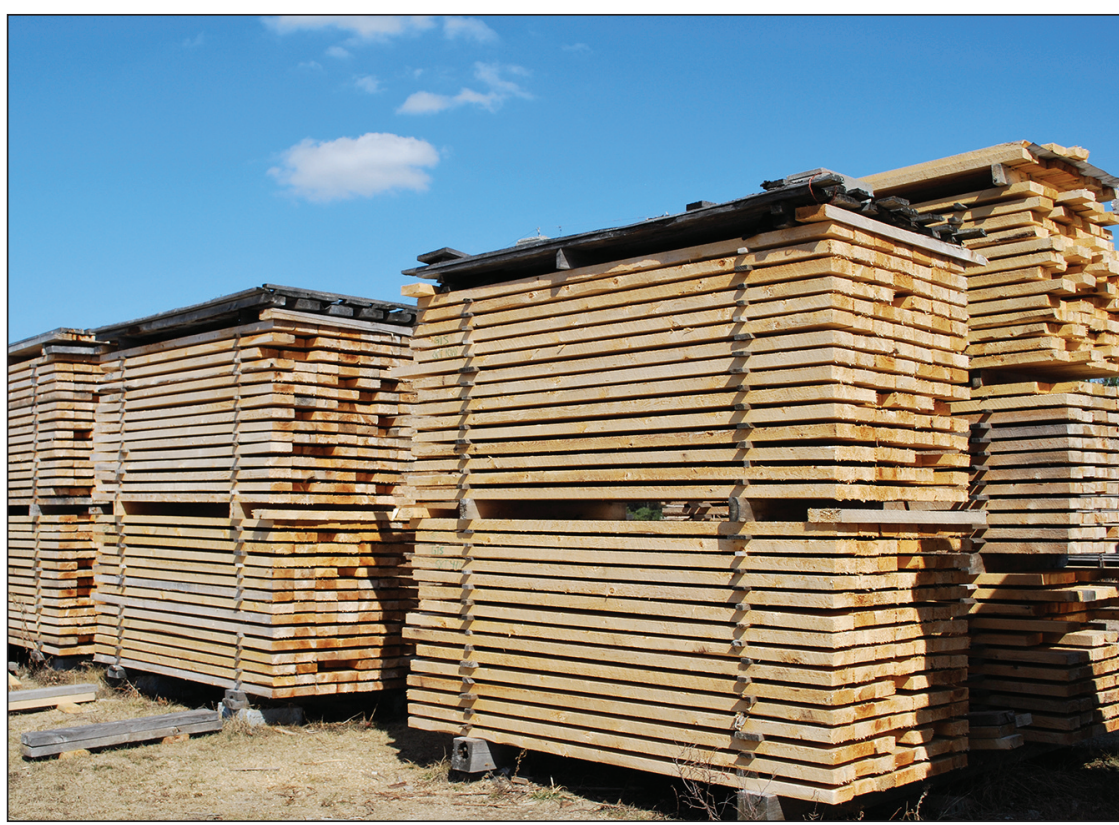

No matter what your building needs, there is a lumber yard somewhere in Renfrew County that can fill your order!

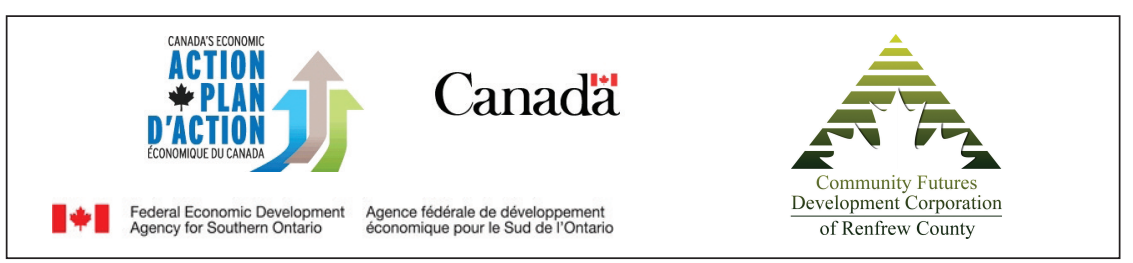

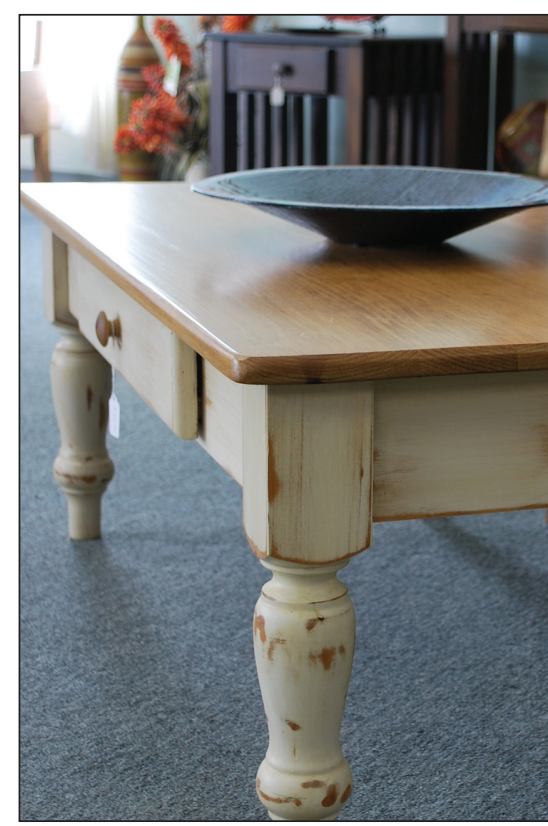

There is a surprising amount of furnituremaking talent in the Valley, from modern to rustic such as this pine table.

mote the long history and sustainability of the forest industry in the area.

County of Renfrew staff, Lacey Rose, forester, and Craig Kelley, Business Development Officer, have been travelling around the County interviewing, learning and documenting the history, business practices and products of over 20 wood producers. They are using this information to create profiles and product lists that will be available on the Web site directory www.OttawaValleyWood.com, to be launched this fall. How does it work? Lacey and Craig gather product information, photos and interesting facts about local wood producers interested in selling to the public, categorize it and put it online. Consumers look under the category of product they are interested in, examine their options, contact the producer and buy directly. Purchasers get to meet members of their community who produce high-quality goods and have a personal story to tell with each purchase. The project is funded by the Eastern Ontario Economic Development Program at no cost to producers. A sample of some of the wood products manufactured in Renfrew County includes: lumber of every species native to eastern 


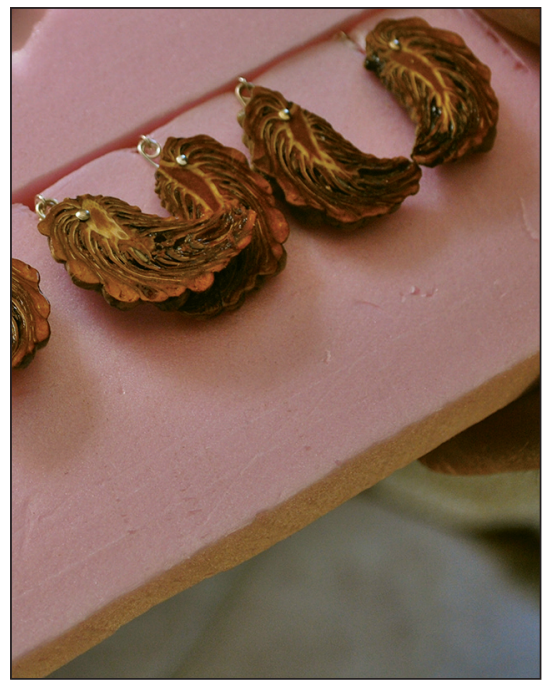

These jack pine cone earrings are just one example of the many works of art made by Ottawa Valley Artisans from local wood.
Ontario (any dimension, pressure treated and dried, rough or finished), cedar shingles, cedar wood chips and planks for barbequing, hard maple kitchen utensils, furniture, hardwood and softwood flooring, mouldings, baseboards and trim, exterior wood siding, wall paneling, roof trusses, fireplace mantels, kitchen cabinets, timber frame and log home building, jewelry and wonderful works of wood art.

The list continues to grow and the project has received positive feedback from many people surprised and pleased to see they have many local buying options and from producers who are proud of the work they do. The County of Renfrew hopes to raise the profile of the sustainable forest management that occurs in the Ottawa Valley and the level of employment that results from wood-in and out of the forest. It is hoped that a sense of community pride will be created in consumers with the ability to support the local economy through informed purchasing. The "100 mile diet" is certainly possible for many of our wood needs.

In the meantime, all the information collected so far is available on Facebook: www.facebook.com/OttawaValleyWood. Make sure to "Like" Ottawa Valley Wood to stay up to date when new producers are added!

Lacey Rose County of Renfrew

This piece was written over 85 years ago, and while the times may have changed the message remains much the same. Many of the image issues facing foresters and the forestry profession today are the same ones that were acknowledged in the earlier part of the 20th century. This article provides an interesting insight into our past, which is very similar to our present and, quite possibly, our future.

\section{Vision in Forest Publicity \\ By R. M. Watt}

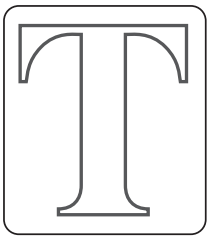

he stride of our modern business world is a rapid one. Today is far ahead of yesterday. Yesterday's publicity was merely the circulating of words on paper. Today's publicity demands graphic presentation by word and picture. Forest publicity is no exception and must keep abreast of the times. If our forest publicity is to sell the idea of forest conservation, our copy must be in no way inferior to the business advertisement with which it competes for public attention. A glance at any first-class magazine will corroborate my statement that the business world is gaining public attention through its striking, unusual and distinctive presentation of the desirability of its products. Here, as in life, it is the survival of the fittest. Mediocre publicity is a waste of money.

Our product, the idea of forest conservation, unlike many commercial products, has year-round demand. It is fundamentally bound up with the industrial development of the nation and there is no season when we can afford to lose sight of this fact. Therefore the Canadian people should be shown that our forests are a permanent endowment of the nation and funds expended in their protection are in the nature of premiums only. We may enjoy today and a hundred years hence the security of our forest estate only in proportion to the extent to which we meet the premiums of this insurance obligation.

We should not be satisfied with merely saying parrot-like slogans. Repetition is excellent; but to be $\% 100$ effective, it must be supplemented by specialized publicity which attracts and interests all classes, all ages, and arouses a desire for action. A well-directed, continuous publicity programme is essential to the success of the 